\title{
Biodiversity loss, emerging pathogens and human health risks
}

\author{
Dirk S. Schmeller ${ }^{1} \cdot$ Franck Courchamp ${ }^{2} \cdot$ Gerry Killeen $^{3}$ \\ Published online: 13 August 2020 \\ (C) Springer Nature B.V. 2020
}

\begin{abstract}
Outbreaks of emerging infectious diseases are occurring with increasing frequency and consequences, including wildlife diseases and zoonoses. Those have potentially longlasting effects on human and wildlife populations, with inevitable direct and indirect effects on ecosystems. The intensifying emergence of infectious pathogens has many underlying reasons, all driven by the growing anthropogenic impact on nature. Intensifying pathogen emergence can be attributed to climate change, biodiversity loss, habitat degradation, and an increasing rate of wildlife-human contacts. All of these are caused by synergies between persisting intense poverty and a growing human population. Improved global management of the human-driven biological degradation and international dispersal processes that exacerbate those pandemic threats are now long overdue. It is vital that we act decisively in the aftermath of the COVID-19 crisis to radically change how we collectively manage the planet as a whole.
\end{abstract}

Keywords Covid-19 $\cdot$ Zoonoses $\cdot$ Pandemics $\cdot$ Disease pyramid $\cdot$ Ecosystem health

\section{Introduction}

In 2020, the global public was abruptly reminded that pandemics can pose a serious threat to public health and economies on worldwide scales. Most people remember that only few years ago the world was threatened by a SARS outbreak, as well as epidemics from avian and porcine strains of flu: $\mathrm{H} 1 \mathrm{~N} 1$ and $\mathrm{H} 5 \mathrm{~N} 1$, respectively. Yet, one of the most comprehensive studies on the topic (Jones et al. 2008) showed that the number of zoonoses have been mounting across the planet in recent decades, augmenting the probability of epidemics and pandemics in the human population. In fact, $75 \%$ of emerging human

Communicated by David Hawksworth.

Dirk S. Schmeller

ds@die-schmellers.de

1 ECOLAB, Université de Toulouse, CNRS, INPT, UPS, Toulouse, France

2 Université Paris-Saclay, CNRS, AgroParisTech, Ecologie Systématique Evolution, 91405 Orsay, France

3 School of Biological, Earth \& Environmental Sciences, and Environmental Research Institute, University College Cork, Cork, Republic of Ireland 
pathogens are zoonotic, meaning they have an animal origin (Taylor et al. 2001). Zoonoses have always existed, but their frequency and their geographic spread are increasing. For example, the simian immunodeficiency virus (SIV) has been regularly infecting individual humans in Central and Eastern Africa for hundreds of years without establishing itself as the transmissible human disease we now know as Acquired Immune Deficiency Syndrome (AIDS). Sustained human-to-human transmission only occurred in the second half of the twentieth century, but such emergence from the zoonotic reservoir has now occurred at least three times, resulting in as many distinct lineages of Human Immunodeficiency Virus (HIV) today (Sharp and Hahn 2011). Perhaps the most significant strategic lesson to be learned from the natural history of HIV is that once such disastrous spill-over events start occurring, they tend to keep occurring until the underlying cause is addressed.

Increasing numbers of wildlife pathogen epidemics have also occurred in recent decades (Fisher et al. 2012), causing epidemics such as the white-nose-syndrome in bats (Blehert et al. 2009), ash-tree diebacks (Pautasso et al. 2013) and the pandemic chytridiomycosis killing amphibians across continents (Fisher et al. 2009). Generally, pathogens are an important component in nature, usually leading to the death of the weakest and/or less adapted individuals only, rendering the remaining population better adapted. Broadly speaking, pathogens are a driving force in the evolution of metazoans (Haldane's hypothesis; Haldane 1932) and some, like malaria, have left an indelible footprint on the human genome (MGE Network 2019; Piel et al. 2010). Pathogens have far reaching and potentially long-lasting impacts on human, animal and plant communities, with inevitable direct and indirect effects on ecosystems. For example, the infamous Scramble for Africa by Europeans was only possible once natural quinine (Cinchona officinalis, Jesuits' Bark) was "discovered" in their other colonies in Latin America, protecting the colonizers from malaria as they pushed into the interior from all along the coast (Rutz 2018). Endemic malaria has stopped many invasions in their tracks and ancient Rome was said to be better protected by its swamps than its armies (Bray 2004). The delayed exploitation of Africa's riches not only protected it against colonization for centuries, it also helped preserve its unique ecosystems and probably averted extinctions of many of the world's most enigmatic large mammals.

These examples show that the outbreak of a disease is linked to manifold interactions between hosts, pathogens, and the environment, forming a disease triangle. A fourth player, which only recently became a focus of scientific studies, is the host microbiome, making the disease triangle a pyramid (Bernardo-Cravo et al. 2020; Fig. 1). The host microbiome allows the host to adjust to its environment, provides protection against pathogens, and contributes to physiological functions. Microbiomes also play crucial roles in ecosystems. The environmental microbiome promotes ecosystem stability and the maintenance of biodiversity by preserving ecosystem health and contributing to important ecological functions. Both host and environmental microbiomes are interconnected and regularly exchange microorganisms, including pathogen, host and environment. Therefore, a given environmental condition interacts simultaneously and independently with the host, the host microbiome and the pathogen in various ways, modifying each directly as well as through their interactions with each other. The four-way interaction of the disease pyramid determines the intensity and severity of the disease outcome from asymptomatic at the periphery to high mortality in the center of the bubble (Bernardo-Cravo et al. 2020; Fig. 1). The disease pyramid illustrates the complexity of the relationship between ecosystem health, wildlife health and human health. To understand pathogen emergence and to predict epidemic risks, we need to understand the four-way interactions of the disease pyramid, including also various anthropogenic impacts, such as pollution, climate change, and land 


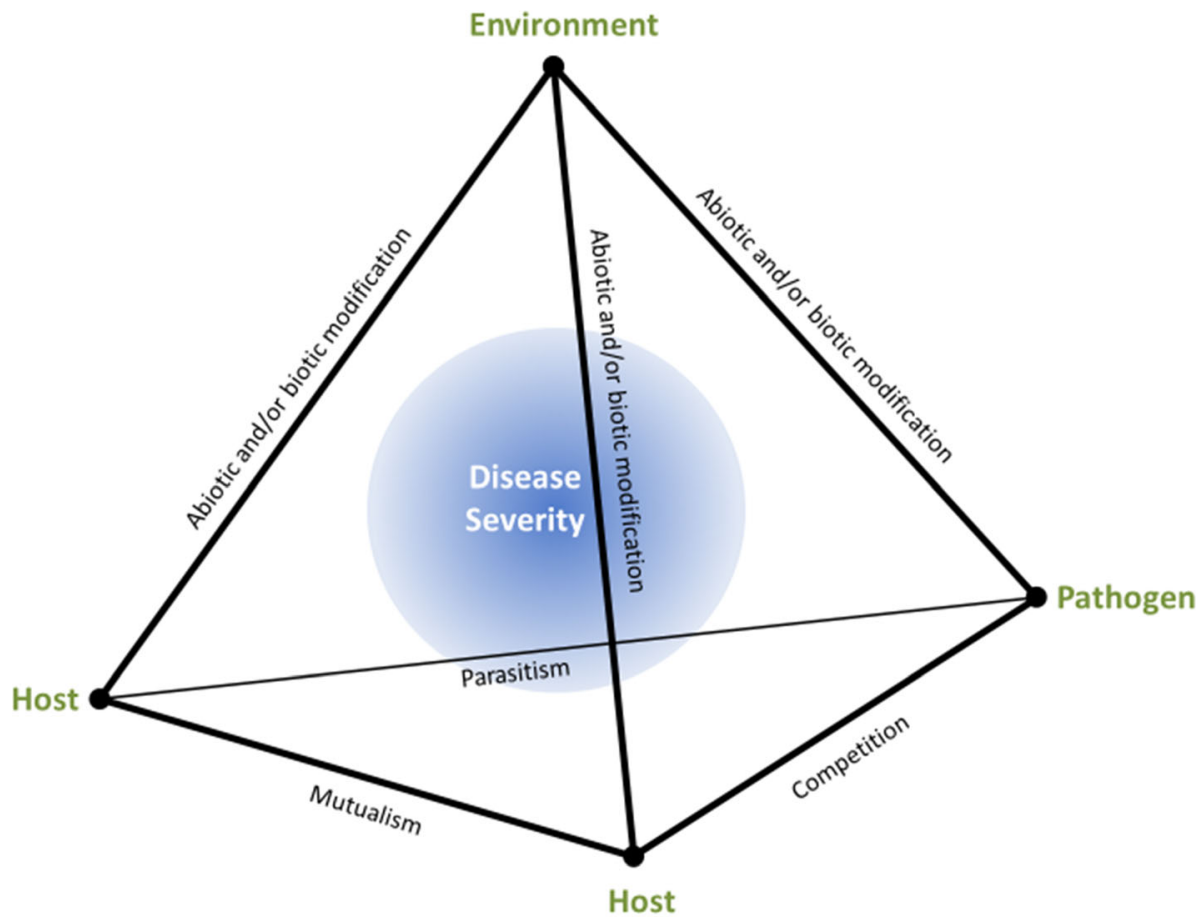

\section{Microbiome}

Fig. 1 The disease pyramid depicting the four-way interaction between host, host microbiome, pathogen and environment. The pyramid illustrates the gradient of host susceptibility determined by resistance and tolerance to a pathogen, pathogen permeability of the host microbiome, pathogenicity determined by the infectivity and virulence of a pathogen, and biotic and abiotic environmental conditions. A given environmental condition interacts simultaneously and independently with the host, the host microbiome and the pathogen in various ways. Each of these four-way interactions feed towards the centre of the pyramid, affecting disease outcome from asymptomatic in the periphery to high mortality in the centre of the bubble Adapted from Bernardo-Cravo et al. (2020)

use (i.e. deforestation, urbanisation, and agricultural intensification), upon them (Schmeller et al. 2018).

We know that the intensifying emergence of infectious pathogens has manifold reasons, all driven by the growing anthropogenic impact on nature. Intensifying emergence can be attributed to climate change, biodiversity loss, habitat degradation, an increasing rate of wildlife-human contacts, and human-driven introductions of pathogens and invasive species through trade and travel (Despommier et al. 2006; Destoumieux-Garzón et al. 2018) (Di Marco et al. 2020; Murray and Daszak 2013).

All of these are caused by synergies between persisting intense poverty and a growing human population, all of which modify interactions between the four components of the disease pyramid. We are profoundly changing our environment, imposing an enormous stress on all components of nature. In addition to stressed populations of wild animals that often suffer several threats simultaneously (habitat loss, overexploitation, pollution, biological invasions, climate change, etc.), increased interactions with humans (directly, or indirectly via their domestic animals) exacerbate the probability of pathogen transfer from wild animals to humans, so a constant stream of new viral pathogens has emerged steadily 
over recent decades (Woolhouse et al. 2012). In addition, we are closing in on nature by destructing whole landscapes, exploiting grasslands for livestock, forests for wood, mining (e.g. Africa), palm plantations (e.g. Southeast Asia) or intensive cattle production (e.g. South America) and rivers for energy and water. Humans have done so for many centuries, but as the human population has grown and increasingly encroached on habitats for wild animals, pathogen transfers into the human host have accelerated. In the Amazon and Congo basins alone, a yearly extraction of six million tons of bushmeat is emptying forests and putting millions of people in contact with wildlife (Nasi et al. 2011).

Wild animals host a vast reservoir of pathogens. For example, together, mammals harbour at least 320,000 undiscovered viruses (Anthony et al. 2013). Similarly, between 88 and $98 \%$ of fungal species are still unknown to science (Hawksworth and Dentinger 2013). It is no wonder then, that zoonotic emerging infectious disease risk is elevated in high biodiversity regions experiencing anthropogenic disturbances (Allen et al. 2017). Therefore, if contact conditions are adequate, the opportunities for pathogen transfer are numerous. Major reservoir hosts include rodents, livestock, carnivores, non-human primates and bats, several of which are carried around by arthropod vectors, such as the invasive Aedes mosquitoes responsible for the recent global spread of Zika virus far beyond Africa (White and Razgour 2020). Often, the behaviour of animal hosts can be altered when their habitats are too affected, which can impact both the pathogens they carry and the probability of transmission to humans (White and Razgour 2020). The more people get in contact with a pathogen, the more probable it will infect and adapt to humans, thus allowing human-to-human transmission (De Vries et al. 2017; Peng et al. 2014). High population densities of humans, often in poor sanitary conditions, as well as intensive farming of poultry, pigs, sheep or cattle, provide ideal conditions for rapid spread of pathogens once they have emerged. For example, the H1N1, H5N1 and Nipah virus originated from wild animal infections of chicken and pigs in extremely dense and physiologically stressed conditions, respectively (Rohr et al. 2019; Verhagen et al. 2011). Globalization and introductions of invasive species, for example translocation of disease vectors like Aedes aegypti and A. albopictus mosquitoes, the most important vectors of Dengue, Chikunguna, and Zika viruses (Gloria-Soria et al. 2016; Musso and Gubler 2015), then lead to anthropogenic spread of emerging pathogens. Many examples of wildlife pathogen outbreaks mediated by human beings have also been documented. Indeed, it is suspected that the spread of the deadly pathogen Batrachochytrium dendrobatidis could be linked to massive troop movements from the Korean Peninsula (O'Hanlon et al. 2018), with subsequent infection of the American bullfrog, an invasive amphibian species now threatening indigenous amphibian communities around the world (Duffus and Cunningham 2010). Just as for zoonotic emerging infections, biological invasions are exponentially increasing worldwide and show no sign of saturation yet (Seebens et al. 2017). Invasive pathogenic microorganisms comprise only a small fraction of all the thousands of alien species currently invasive somewhere on the globe, many of which have devastating impacts on biodiversity, ecosystem functioning, and human health and economies (Pyšek et al. 2020). International trade has also been pinpointed as a major threat to biodiversity, livestock, bees and human society due to movements of emerging or re-emerging pathogens (Auliya et al. 2016; Owen 2017; Sherman 2011; Travis et al. 2011). Following from the disease pyramid, all these impacts can fragilize ecosystems and can negatively impact upon human well-being. Based on observations over recent decades, we should expect continued increase in the frequency of epidemics caused by newly emerging pathogens (Fisher et al. 2012; Jones et al. 2008). Politicians, policy makers, and stakeholders also need to be aware that the most dangerous emerging pathogens are unknown to science and 
cannot be readily detected through quarantine or border controls. A revaluation of trade rules is therefore needed considering the current incomplete knowledge of the countless pathogenic viruses, bacteria and fungi capable of causing adverse effects upon wildlife, livestock and human well-being.

The ongoing crisis caused by the 2019 novel coronavirus (COVID-19) is the most obvious and urgent example of an emerging zoonotic pathogen, in this case apparently transferred from not one but two wild species, specifically a recombination hybrid of bat and pangolin viruses (Lam et al. 2020), and then spreading rapidly across the world thanks to our hyper-connected, globalised human civilization. The ongoing adaptation of the virus to humans (Pachetti et al. 2020), which accelerates as we allow the viral population to grow in size, only adds to the case for saying that the dangers of such pandemics can't be overstressed. The mortality rates of $40-75 \%$ of humans infected by the Nipah virus (Jose 2018), and even higher fatality rates for Ebola during the earliest, least mitigated phase of an outbreak (Schieffelin et al. 2014), illustrate just how much worse the current Covid-19 pandemic could be.

Despite the far lower infection fatality rate of just over 1\% (Verity et al. 2020), COVID19 has already led to plummeting economies and serious social distress worldwide. Looking ahead, further pandemic crises, some caused by worse pathogens than SARSCov2, will be no less difficult to handle socially and economically. In a global assessment of biodiversity, the Intergovernmental Science-Policy Platform for Biodiversity and Ecosystem Services (IPBES, (Bridgewater et al. 2019), has called for a transformative change in the human society. We need to realize that habitat destruction, overexploitation and transportation of species, industrial farming, and the ever-increasing volume of worldwide travel (before the crisis, one plane was taking off every second) all destabilize our environment and favour the spread of pathogens. All these factors increase the probability of disease severity both in wildlife as well as in the human population. We need to rethink our relationship with nature and with the world's poorest, most neglected populations to minimize future catastrophic epidemics. Perhaps the most poignant current example lies in eastern Democratic Republic of Congo (DRC), an area of exceptional biodiversity and ecological value but also protracted human conflict, associated entrenched poverty, endemic infectious disease burden and perpetual threat of emerging infections. The misfortunes of people living in the eastern DRC were largely ignored by the rest of the world until they suffered an Ebola outbreak that threatened all of us:

"With a population of 80 million, the DRC has more than 4 million displaced and is home to the world's second largest food crisis with 13 million people food insecure. Since January 2019, there have been outbreaks of cholera (15,331 cases, 287 deaths), measles (161,397 cases, 3,117 deaths) and malaria, the leading cause of death in the DRC, which kills more than 48,000 people every year" (WHO 2019). After decades of chronic and brutal conflict, including dozens of attacks on Ebola response workers, a long-overdue cease-fire was finally brokered that enabled not only Ebola containment but also strengthening of local health systems generally. At the time of writing, the Ebola outbreak in the eastern DRC was still ongoing and remains a Public Health Emergency of International Concern, meaning a persisting pandemic threat to the world at large (WHO 2020). We suggest there is valuable food for thought in the observation that the dangerous lingering tail of this latest Ebola outbreak, the second largest in history, featured alongside the need to protect healthcare workers from COVID-19 in two editorials on the same page of The Lancet (Anonymous 2020a, b).

Nothing less than our entire global society is at risk from pandemic threats, food insecurity (Fisher et al. 2012), and lack of access to drinking water (Schmeller et al. 2018). 
Shortages of natural resources lead to societal unrest and geopolitical instability that leave us vulnerable. We need to be more restrictive in regard to wildlife food consumption (Yang et al. 2020), wildlife transportation and trade, deforestation, mining, and industrial livestock farming (Chang 2020). The COVID-19 crisis as well as past and future epidemics underline the points raised in the global assessment of IPBES that everything is interconnected, the health of animals, the health of nature, and the health of humans. The One Health concept (Destoumieux-Garzón et al. 2018) captures this interconnectedness and has gained traction in the policy arena. The EU Regulation (EU) 2019/4 of the European Parliament and of the Council from the 11 December 2018 has amended Regulation (EC) No 183/2005 of the European Parliament, explicitly mentioning the One Health Concept, repealing Council Directive 90/167/EEC. Despite the political relevance, there appears to be a disconnect between the perception of climate change, biodiversity loss, epidemic threats and fear for one's own life: we all need to understand that these are not someone else's problem and that earlier epidemics, such as SARS1, MERS, and Ebola were only contained within their regions of origin with enormous efforts required to finally extinguish these outbreaks (Suwantarat and Apisarnthanarak 2015). We are now faced with a quartet of increasingly urgent and interrelated global challenges, specifically climate change, biodiversity loss, ecosystem degradation and global reshuffling of invasive organisms (including emerging zoonotic infections), all of which we can only be resolved with the kind of global solidarity emphasized by Dr Tedros Ghebreyesus in relation to COVID-19 containment (WHO 2020). Improved global management of the human-driven biological degradation and international dispersal processes that increasingly exacerbate those pandemic threats are now long overdue. It is vital that we act decisively in the aftermath of the COVID-19 crisis to radically change how we collectively manage the planet as a whole.

We invite contributions to Biodiversity and Conservation studying or reviewing the link between emerging pathogens and human impacts, as well as the risks for wildlife and the human society.

Acknowledgements We thank Adeline Loyau for critical comments on an earlier version of the manuscript.

\section{References}

Allen T, Murray KA, Zambrana-Torrelio C, Morse SS, Rondinini C, Di Marco M, Breit N, Olival KJ, Daszak P (2017) Global hotspots and correlates of emerging zoonotic diseases. Nat Commun 8:1-10 Anonymous (2020a) COVID-19: protecting health-care workers. Lancet 395:922. https://doi.org/10.1016/ S0140-6736(20)30644-9

Anonymous (2020b) Ebola in DR Congo: getting the job done. Lancet 395:922. https://doi.org/10.1016/ S0140-6736(20)30645-0

Anthony SJ, Epstein JH, Murray KA, Navarrete-Macias I, Zambrana-Torrelio CM, Solovyov A, OjedaFlores R, Arrigo NC, Islam A, Khan SA, Hosseini P, Bogich TL, Olival KJ, Sanchez-Leon MD, Karesh WB, Goldstein T, Luby SP, Morse SS, Mazet JAK, Daszak P, Lipkin WI (2013) A strategy to estimate unknown viral diversity in mammals. MBio 4:e00598-e1513

Auliya M, García-Moreno J, Schmidt BR, Schmeller DS, Hoogmoed MS, Fisher MC, Pasmans F, Henle K, Bickford D, Martel A (2016) The global amphibian trade flows through Europe: the need for enforcing and improving legislation. Biodivers Conserv. https://doi.org/10.1007/s10531-016-1193-8

Bernardo-Cravo A, Schmeller DS, Chatzinotas A, Vredenburg VT, Loyau A (2020) Environmental factors and host microbiomes shape host-pathogen dynamics. Trends Parasitol 36:29-36

Blehert DS, Hicks AC, Behr M, Meteyer CU, Berlowski-Zier BM, Buckles EL, Coleman JTH, Darling SR, Gargas A, Niver R, Okoniewski JC, Rudd RJ, Stone WB (2009) Bat white-nose syndrome: an emerging fungal pathogen? Science 323:227. https://doi.org/10.1126/science.1163874

Bray RS (2004) Armies of pestilence: the impact of disease on history. James Clarke \& Co., Cambridge 
Bridgewater P, Loyau A, Schmeller DS (2019) The seventh plenary of the intergovernmental platform for biodiversity and ecosystem services (IPBES-7): a global assessment and a reshaping of IPBES. Biodivers Conserv 28:2457-2461. https://doi.org/10.1007/s10531-019-01804-w

Chang J (2020) China's legal response to trafficking in wild animals: the relationship between International Treaties and Chinese Law. Studies in global animal law. Springer, Berlin, pp 71-79

De Vries RP, Peng W, Grant OC, Thompson AJ, Zhu X, Bouwman KM, de la Pena ATT, van Breemen MJ, Wickramasinghe INA, de Haan CA (2017) Three mutations switch H7N9 influenza to human-type receptor specificity. PLoS Pathog 13:1006390

Despommier D, Ellis B, Wilcox B (2006) The role of ecotones in emerging infectious diseases. EcoHealth 3:281-289. https://doi.org/10.1007/s10393-006-0063-3

Destoumieux-Garzón D, Mavingui P, Boetsch G, Boissier J, Darriet F, Duboz P, Fritsch C, Giraudoux P, Le Roux F, Morand S, Paillard C, Pontier D, Sueur C, Voituron Y (2018) The one health concept: 10 years old and a long road ahead. Front Vet Sci. https://doi.org/10.3389/fvets.2018.00014

Di Marco M, Baker ML, Daszak P, De Barro P, Eskew EA, Godde CM, Harwood TD, Herrero M, Hoskins AJ, Johnson E (2020) Opinion: sustainable development must account for pandemic risk. Proc Natl Acad Sci USA 117:3888-3892

Duffus A, Cunningham AA (2010) Major disease threats to European amphibians. Herpetol J 20:117-127

Fisher MC, Garner TWJ, Walker SF (2009) Global emergence of Batrachochytrium dendrobatidis and amphibian chytridiomycosis in space, time and host. Annu Rev Microbiol. https://doi.org/10.1146/ annurev.micro.091208.073435

Fisher MC, Henk DA, Briggs CJ, Brownstein JS, Madoff LC, McCraw SL, Gurr SJ (2012) Emerging fungal threats to animal, plant and ecosystem health. Nature 484:186-194

Gloria-Soria A, Ayala D, Bheecarry A, Calderon-Arguedas O, Chadee DD, Chiappero M, Coetzee M, Elahee KB, Fernandez-Salas I, Kamal HA, Kamgang B, Khater EIM, Kramer LD, Kramer V, LopezSolis A, Lutomiah J, Martins A Jr, Micieli MV, Paupy C, Ponlawat A, Rahola N, Rasheed SB, Richardson JB, Saleh AA, Sanchez-Casas RM, Seixas G, Sousa CA, Tabachnick WJ, Troyo A, Powell JR (2016) Global genetic diversity of Aedes aegypti. Mol Ecol 25:5377-5395. https://doi.org/10.1111/ mec. 13866

Haldane JB (1932) The causes of evolution (reprint 1990). Princeton University Press, Princeton

Hawksworth DL, Dentinger BTM (2013) Antibiotics: relax UK import rule on fungi. Nature 496:169-169. https://doi.org/10.1038/496169b

Jones KE, Patel NG, Levy MA, Storeygard A, Balk D, Gittleman JL, Daszak P (2008) Global trends in emerging infectious diseases. Nature 451:990-993

Jose B (2018) Nipah: The deadly menace. J Acad Clin Microbiol 20:66-73. https://doi.org/10.4103/jacm. jacm_34_18

Lam TT-Y, Shum MH-H, Zhu H-C, Tong Y-G, Ni X-B, Liao Y-S, Wei W, Cheung WY-M, Li W-J, Li L-F, Leung GM, Holmes EC, Hu Y-L, Guan Y (2020) Identifying SARS-CoV-2 related coronaviruses in Malayan pangolins. Nature. https://doi.org/10.1038/s41586-020-2169-0

MGE Network (2019) Insights into malaria susceptibility using genome-wide data on 17,000 individuals from Africa, Asia and Oceania. Nat Commun 10:5732

Murray KA, Daszak P (2013) Human ecology in pathogenic landscapes: two hypotheses on how land use change drives viral emergence. Curr Opin Virol 3:79-83

Musso D, Gubler DJ (2015) Zika virus: following the path of dengue and chikungunya? Lancet 386:243-244

Nasi R, Taber A, Van Vliet N (2011) Empty forests, empty stomachs? Bushmeat and livelihoods in the Congo and Amazon Basins. Int For Rev 13:355-368

O'Hanlon SJ, Rieux A, Farrer RA, Rosa GM, Waldman B, Bataille A, Kosch TA, Murray KA, Brankovics B, Fumagalli M, Martin MD, Wales N, Alvarado-Rybak M, Bates KA, Berger L, Böll S, Brookes L, Clare F, Courtois EA, Cunningham AA, Doherty-Bone TM, Ghosh P, Gower DJ, Hintz WE, Höglund J, Jenkinson TS, Lin C-F, Laurila A, Loyau A, Martel A, Meurling S, Miaud C, Minting P, Pasmans F, Schmeller DS, Schmidt BR, Shelton JMG, Skerratt LF, Smith F, Soto-Azat C, Spagnoletti M, Tessa G, Toledo LF, Valenzuela-Sánchez A, Verster R, Vörös J, Webb RJ, Wierzbicki C, Wombwell E, Zamudio KR, Aanensen DM, James TY, Gilbert MTP, Weldon C, Bosch J, Balloux F, Garner TWJ, Fisher MC (2018) Recent Asian origin of chytrid fungi causing global amphibian declines. Science 360:621-627. https://doi.org/10.1126/science.aar1965

Owen R (2017) Role of human action in the spread of honey bee (Hymenoptera: Apidae) pathogens. J Econ Entomol 110:797-801

Pachetti M, Marini B, Benedetti F, Giudici F, Mauro E, Storici P, Masciovecchio C, Angeletti S, Ciccozzi M, Gallo RC, Zella D, Ippodrino R (2020) Emerging SARS-CoV-2 mutation hot spots include a novel RNA-dependent-RNA polymerase variant. J Transl Med 18:179. https://doi.org/10.1186/s12967-02002344-6 
Pautasso M, Aas G, Queloz V, Holdenrieder O (2013) European ash (Fraxinus excelsior) dieback-a conservation biology challenge. Biol Conserv 158:37-49

Peng J, Yang H, Jiang H, Lin Y-x, Lu CD, Xu Y-w, Zeng J (2014) The origin of novel avian influenza A (H7N9) and mutation dynamics for its human-to-human transmissible capacity. PLoS ONE 9:e93094

Piel FB, Patil AP, Howes RE, Nyangiri OA, Gething PW, Williams TN, Weatherall DJ, Hay SI (2010) Global distribution of the sickle cell gene and geographical confirmation of the malaria hypothesis. Nat Commun 1:1-7

Pyšek P, Hulme PE, Simberloff D, Bacher S, Blackburn TM, Carlton JT, Dawson W, Essl F, Foxcroft LC, Genovesi P (2020) Scientists' warning on invasive alien species. Biol Rev. https://doi.org/10.1111/brv. 12627

Rohr JR, Barrett CB, Civitello DJ, Craft ME, Delius B, DeLeo GA, Hudson PJ, Jouanard N, Nguyen KH, Ostfeld RS, Remais JV, Riveau G, Sokolow SH, Tilman D (2019) Emerging human infectious diseases and the links to global food production. Nat Sustain 2:445-456. https://doi.org/10.1038/s41893-0190293-3

Rutz MA (2018) King Leopold's Congo and the "scramble for Africa": a short history with documents. Hackett Publishing, Indianapolis

Schieffelin JS, Shaffer JG, Goba A, Gbakie M, Gire SK, Colubri A, Sealfon RS, Kanneh L, Moigboi A, Momoh M (2014) Clinical illness and outcomes in patients with Ebola in Sierra Leone. N Engl J Med 371:2092-2100

Schmeller DS, Loyau A, Bao K, Brack W, Chatzinotas A, De Vleeschouwer F, Friesen J, Gandois L, Hansson SV, Haver M, Le Roux G, Shen J, Teisserenc R, Vredenburg VT (2018) People, pollution and pathogens: global change impacts in mountain freshwater ecosystems. Sci Total Environ 622-623:756-763. https://doi.org/10.1016/j.scitotenv.2017.12.006

Seebens H, Blackburn TM, Dyer EE, Genovesi P, Hulme PE, Jeschke JM, Pagad S, Pyšek P, Winter M, Arianoutsou M (2017) No saturation in the accumulation of alien species worldwide. Nat Commun 8:1-9

Sharp P, Hahn B (2011) Origins of HIV and the AIDS pandemic. Cold Spring Harb Perspect Med 1:a006841

Sherman D (2011) The spread of pathogens through trade in small ruminants and their products. Revue Scientifique et Technique-OIE 30:207

Suwantarat N, Apisarnthanarak A (2015) Risks to healthcare workers with emerging diseases: lessons from MERS-CoV, Ebola, SARS, and avian flu. Curr Opin Infect Dis 28:349-361

Taylor LH, Latham SM, Woolhouse MEJ (2001) Risk factors for human disease emergence. Phil Trans R Soc Lond B 356:983-989

Travis D, Watson R, Tauer A (2011) The spread of pathogens through trade in wildlife. Revue Scientifique et Technique-OIE 30:219

Verhagen JH, Fouchier RA, Munster VJ (2011) Ecology of avian viruses. Stud Viral Ecol 2:365-394

Verity R, Okell LC, Dorigatti I, Winskill P, Whittaker C, Imai N, Cuomo-Dannenburg G, Thompson H, Walker PG, Fu H (2020) Estimates of the severity of coronavirus disease 2019: a model-based analysis. Lancet Infect Dis. https://doi.org/10.1016/S1473-3099(20)30243-7

White RJ, Razgour O (2020) Emerging zoonotic diseases originating in mammals: a systematic review of effects of anthropogenic land-use change. Mammal Rev. https://doi.org/10.1111/mam.12201

WHO (2019) As Ebola cases reach 3000 in DRC, WHO calls on all partners to fulfill promises to communities. https://www.who.int/news-room/detail/29-08-2019-as-ebola-cases-reach-3000-in-drc-whocalls-on-partners-to-fulfill-promises-to-communities. Accessed 18 June 2020

WHO (2020) WHO Director-General's Statement on IHR Emergency Committee on Ebola Virus Disease in the Democratic Republic of the Congo. https://www.who.int/news-room/detail/14-04-2020-whodirector-general-s-statement-on-ihr-emergency-committee-on-ebola-virus-disease-in-the-democraticrepublic-of-the-congo. Accessed 18 June 2020

Woolhouse M, Scott F, Hudson Z, Howey R, Chase-Topping M (2012) Human viruses: discovery and emergence. Philos Trans R Soc B 367:2864-2871

Yang N, Liu P, Li W, Zhang L (2020) Permanently ban wildlife consumption. Science 367:1434-1434. https://doi.org/10.1126/science.abb1938

Publisher's Note Springer Nature remains neutral with regard to jurisdictional claims in published maps and institutional affiliations. 